\title{
ELECTROMECHANICAL SECATEURS BASED ON LINEAR ELECTRIC MOTOR AND DETERMINATION OF CUTTING FORCE OF BRANCHES OF FRUIT TREES
}

\author{
Sergey Antonov, Gennady Nikitenko, Vitaly Grinchenko, Anatoly Molchanov, Valentina Avdeeva \\ Stavropol State Agrarian University, Russia \\ antonov_serg@mail.ru, nikitenko_gv@mail.ru, grinchen_ko@mail.ru, \\ molchanov_41@mail.ru, avdeeva_vn@mail.ru
}

\begin{abstract}
Pruning trees is one of the most laborious processes in fruit growing. The level of mechanization, electrification and automation of caring for fruit trees is high, but a number of technological operations are carried out manually. The use of manual labor when pruning tree branches leads to a decrease in the productivity of workers and makes their work ineffective. The use of a manual electrified tool will improve the efficiency of the technology of detailed tree trimming. The existing Russian secateurs have disadvantages that prevent their wide introduction into production. These drawbacks are the use of asynchronous electric motors and an electric current source of increased frequency, large mass and overall dimensions. Foreign analogs of secateurs have improved mass and dimensional indicators, but have a high cost. Taking into account all the mentioned disadvantages, electromechanical secateurs based on a linear electric motor are offered, which have the following set of properties: low power consumption, easy maintenance, high operational reliability, small weight and overall dimensions, high speed. These advantages of the secateurs are achieved by using a linear electric motor. The main advantage of the linear electric drive is the lack of transmission, it is easy to manufacture, reliable in operation and has a high speed. The main parameter for calculating the linear electric motor is the cutting force of the branches. Fruit trees have a certain hardness, which depends on the temperature and humidity of the environment. For successful trimming of fruit tree branches, the optimal combination of the mechanical characteristics of the cutting pair and the linear electric drive is necessary.
\end{abstract}

Keywords: electromotor, secateurs, hacksaw, power, electrotechnology.

\section{Introduction}

Pruning fruit trees is carried out for their formation, control of fruiting and growth, improving crown lighting, rejuvenating, improving the quality of fruits, as well as removing sick, broken and dry branches. Important for the effective development of domestic gardening is the mechanization of the process of detailed pruning of fruit trees, using electrified hand tools.

Analysis of existing tools for detailed pruning fruit trees, allowed determining the following types of tools: manual, pneumatic, hydraulic and electric. The cheapest is the hand tool, but the labor costs are much higher than for the rest. Pneumatic tools reduce labor costs for trimming, but they have a number of disadvantages: low reliability of the pneumatic system; short service life; significant reduction in the characteristics of the cut during operation; vibration; limited range of work. Hydraulic tool in comparison with pneumatic, has an extended period of operation and reliability, but it also has characteristic drawbacks. The disadvantages include the danger of malfunctions in the hydraulic system, the complexity of repair in the field, large mass, lack of mobility. The application of the electric drive is most effective according to the analysis of domestic and foreign scientists. According to their data, the use of an electrified tool allows you to reduce the labor costs to $10 \%$ of manual pruning. An electrified tool for trimming fruit trees uses an asynchronous electric motor or a DC machine [1;2]. Disadvantages of a secateur with an asynchronous motor are the availability of current frequency converters, which can vary from 50 to $200 \mathrm{~Hz}$, large vibration and weight and dimensions, as well as a small radius of work. The secateurs with a DC machine are characterized by the presence of a battery, which during operation is susceptible to rapid discharge and negatively affects the weight and dimensions.

For the drive of secateurs, the most promising ones are linear electric motors. The advantage of linear motors is the lack of transmission, ease of manufacture, high reliability during operation, speed and low power consumption.

At the department "Using electricity in agriculture", the FSBI HE Stavropol State Agrarian University developed the secateurs based on a linear electric motor (Fig. 1), which consist of a movable (1) and fixed (2) blade, an armature (3), a linear electric motor (4), a trigger (5), a battery (6) and a spring (7) [3]. The proposed device operates as follows: when the operator presses the trigger (5) on the linear motor (4), the battery is powered by the battery (6). The anchor (3) under the influence of 
electromagnetic forces comes into motion and moves to the left, driving the movable blade (1). The stationary blade (2) serves as an abutment necessary for cutting tree branches. When the trigger (1) is returned to the initial position, the battery power (6) from the linear motor (4) is disconnected and the armature (3) returns to its first position [4] under the action of the spring (7).

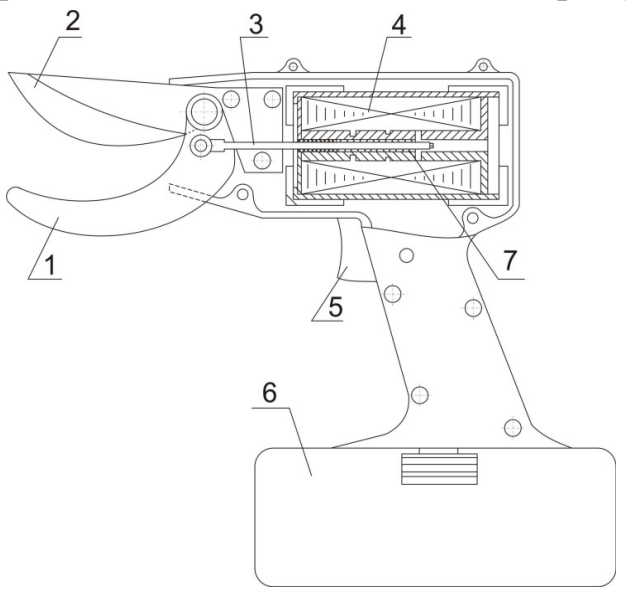

Fig. 1. Section of secateurs based on linear motor

The presented secateurs have improved mass-size indicators, increased reliability, reduced operating costs. Due to the speed of the linear electric motor and the absence of transmission, the cutting force increases with the reduction of the electric power consumption. The advantages of the linear motor-based secateurs mentioned above make them more competitive in the market for electrified and mechanized garden care products.

\section{Materials and methods}

To determine the design parameters of a linear motor, it is necessary to know the cutting characteristics of the material. The tree is an elasto-viscous material; therefore the cutting characteristics cannot be described by strict analytical expressions. To understand the real physical picture of this process, one can come up with a combination of theoretical and experimental studies.

The theoretical substantiation of the process of cutting elastic materials is given [5]. According to [5], the separation of the material into parts begins with a precompression to the point, at which a destructive stress arises at the edge of the blade. The moment, at which the cutting process begins, characterizes the cut force $P_{\text {cut }}$ applied to the blade from the linear motor. At the time of the initial cutting, the blade is deepened into a material of thickness $\mathrm{h}$ by an amount $h_{\text {com }}$ (the thickness of the material compression) (Fig. 2). At this time the following forces $P_{\text {des }}$ (resistance to material destruction, under the sharp edge of the blade, directed upward) act on the blade, $P_{c}$ (force of compression by the material acts on the lateral edges of the blade, having a horizontal direction), $P_{c o m}$ (resistance to compression of the material directed upwards).

The total compressive force $P_{\Sigma c o m}$ acts on the chamfer of the blade, which is directed normally to it and is determined by the formula:

$$
P_{\Sigma \mathrm{com}}=P_{\mathrm{com}} \cdot \sin \beta+P_{\mathrm{c}} \cos \beta
$$

The compression force of a layer of a chamfered material is defined as:

$$
P_{\mathrm{com}}=E \frac{h_{\mathrm{com}}^{2}}{\mathrm{~h}} \operatorname{tg} \beta
$$

where $E$ - elastic modulus.

The force compressing the chamfer is:

$$
P_{\mathrm{c}}=\mu \frac{E}{2} \frac{h_{\mathrm{com}}^{2}}{\mathrm{~h}}
$$

where $\mu$ - Poisson's ratio. 


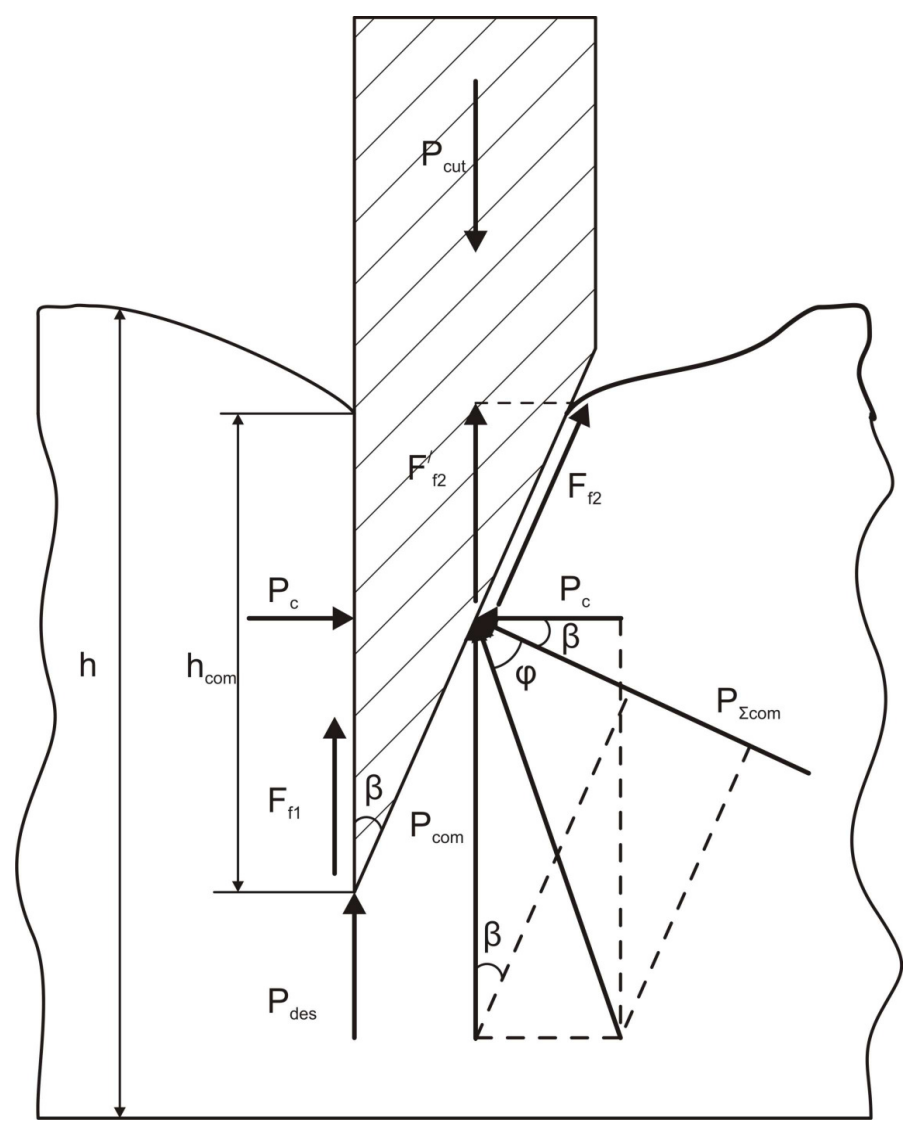

Fig. 2. Interaction of blade with material

As the chamfer slides along the material, a frictional force arises that is defined as:

$$
F_{\mathrm{f} 2}=P_{\Sigma \mathrm{com}} f,
$$

where $f=\operatorname{tg} \varphi-$ coefficient of the chamfer friction on the material;

$\varphi-$ angle of friction.

Through the angle of friction, the friction force of the chamfer is defined as:

$$
F_{\mathrm{f} 2}=\sqrt{P_{c}^{2}+P_{\text {com }}^{2}} \cos \varphi .
$$

On the other side of the blade there is a frictional force of the edge of the blade, which is directed vertically upwards:

$$
F_{\mathrm{f} 1}=P_{\mathrm{c}} f .
$$

The vertical projection of the friction force of a chamfer is determined from expression:

$$
F_{\mathrm{f} 2}^{\prime}=F_{\mathrm{f} 2} \cos \beta .
$$

Taking into account the expressions given above, the cutting force required to break the material is:

$$
P_{\mathrm{cut}}=P_{\mathrm{des}}+P_{\Sigma \mathrm{com}}+F_{\mathrm{f} 1}+F_{\mathrm{f} 2}^{\prime} .
$$

Experimental justification of the cutting process involves determining the cutting force through the hardness of the material by the formula

$$
P_{\text {cut }}=H S,
$$

where $H$-hardness of the material, $\mathrm{MPa}$;

$S$ - cutting area, $\mathrm{m}^{2}$. 
In the thesis [6-8] it is indicated that the hardness of fruit wood depends on its humidity (accuracy up to $1 \%$ ) and ambient temperature (the information is given in Table 1).

Table 1

Hardness of fruit wood, depending on its humidity and ambient temperature (MPa)

\begin{tabular}{|c|c|c|c|c|c|c|c|c|c|c|c|c|c|c|c|}
\hline \multirow{4}{*}{ Crop, variety } & \multicolumn{15}{|c|}{ Temperature, ${ }^{0} \mathrm{C}$} \\
\hline & \multirow{2}{*}{\multicolumn{5}{|c|}{$\begin{array}{c}-10 \\
\text { Humidity, \% }\end{array}$}} & \multirow{2}{*}{\multicolumn{5}{|c|}{$\begin{array}{c}\text { 0 } \\
\text { Humidity, \% }\end{array}$}} & \multirow{2}{*}{\multicolumn{5}{|c|}{$\begin{array}{c}+10 \\
\text { Humidity, \% }\end{array}$}} \\
\hline & & & & & & & & & & & & & & & \\
\hline & 10 & 20 & 30 & 40 & 50 & 10 & 20 & 30 & 40 & 50 & 10 & 20 & 30 & 40 & 50 \\
\hline $\begin{array}{c}\text { Apple tree, } \\
\text { Red Delicious }\end{array}$ & 46.6 & 42.3 & 42.1 & 42.0 & 42.3 & 40.1 & 35.3 & 31.2 & 30.2 & 30.6 & 33.6 & 29.8 & 28.7 & 26.3 & 26.5 \\
\hline $\begin{array}{c}\text { Pear, } \\
\text { Lesnaya krasavitza }\end{array}$ & 38.7 & 35.5 & 35.1 & 35.2 & 35.3 & 30.4 & 28.3 & 28.2 & 28.3 & 28.4 & 26.9 & 24.7 & 25.0 & 24.3 & 25.1 \\
\hline $\begin{array}{c}\text { Grape, } \\
\text { Izabella }\end{array}$ & 33.3 & 27.8 & 25.4 & 25.2 & 25.4 & 25.7 & 22.9 & 21.2 & 21.3 & 21.4 & 21.5 & 19.1 & 18.5 & 16.5 & 16.8 \\
\hline $\begin{array}{l}\text { Gooseberry, } \\
\text { Hauton }\end{array}$ & 46.8 & 43.2 & 40.0 & 40.1 & 40.1 & 42.8 & 38.2 & 37.6 & 36.4 & 36.4 & 37.8 & 36.1 & 33.6 & 32.8 & 34.1 \\
\hline
\end{tabular}

The thickness of the movable blade of the pruner is not more than $2 \mathrm{~mm}$. Proceeding from this, the equivalent thickness of the cutting edge of the blade is recommended no more than $1 \mathrm{~mm}$. The maximum value of the diameter of the cut branches of fruit trees by a secateur, taken from the analysis of scientific literature, does not exceed $30 \mathrm{~mm}$. Proceeding from this, it is possible to compile a visual model of cutting a branch of a fruit tree with a diameter of $30 \mathrm{~mm}$.

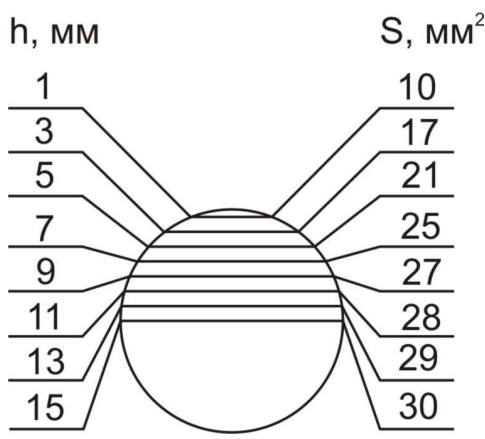

Fig. 3. Model of cross-section of fruit tree branch

Simulation of the cutting process is necessary for constructing the mechanical characteristics of the pruner blade. When the blade penetrates the depth $\mathrm{h}(\mathrm{mm})$ of the branch of the fruit tree, the area affecting the branch cut will be $\mathrm{S}\left(\mathrm{mm}^{2}\right)$. Using the presented model and the results of the study [6], it is possible to determine the force created by a linear electric motor for cutting branches of fruit trees.

\section{Results and discussion}

In accordance with the technology of garden care, pruning is recommended to be done at plus temperatures, before the active sap movement. Proceeding from this, the necessary force (accuracy up to $2.5 \%$ ) is calculated for pruning branches at temperatures from $0{ }^{\circ} \mathrm{C}$ to $+10{ }^{\circ} \mathrm{C}$ and humidity $10 \%$, the results are presented in Tables $2 ; 3$.

Table 2

Cutting force of branches at temperature $0{ }^{\circ} \mathrm{C}$ and humidity $10 \%$ (N)

\begin{tabular}{|c|c|c|c|c|c|c|c|c|}
\hline \multirow{2}{*}{ Crop, variety } & \multicolumn{9}{|c|}{ Penetration depth, mm } \\
\cline { 2 - 9 } & $\mathbf{1}$ & $\mathbf{3}$ & $\mathbf{5}$ & $\mathbf{7}$ & $\mathbf{9}$ & $\mathbf{1 1}$ & $\mathbf{1 3}$ & $\mathbf{1 5}$ \\
\hline Apple tree, Red Delicious & 401 & 682 & 842 & 1003 & 1083 & 1123 & 1163 & 1203 \\
\hline Pear, Lesnaya krasavitza & 304 & 517 & 638 & 760 & 821 & 851 & 882 & 912 \\
\hline Grape, Izabella & 357 & 607 & 750 & 893 & 964 & 1000 & 1035 & 1071 \\
\hline Gooseberry, Hauton & 428 & 728 & 899 & 1070 & 1156 & 1198 & 1241 & 1284 \\
\hline
\end{tabular}


Cutting force of branches at temperature $+10{ }^{\circ} \mathrm{C}$ and humidity $10 \%(\mathrm{~N})$

\begin{tabular}{|c|c|c|c|c|c|c|c|c|}
\hline \multirow{2}{*}{ Crop, variety } & \multicolumn{9}{|c|}{ Penetration depth, mm } \\
\cline { 2 - 9 } & $\mathbf{1}$ & $\mathbf{3}$ & $\mathbf{5}$ & $\mathbf{7}$ & $\mathbf{9}$ & $\mathbf{1 1}$ & $\mathbf{1 3}$ & $\mathbf{1 5}$ \\
\hline Apple tree, Red Delicious & 336 & 571 & 706 & 840 & 907 & 941 & 974 & 1008 \\
\hline Pear, Lesnaya krasavitza & 269 & 457 & 565 & 673 & 726 & 753 & 780 & 807 \\
\hline Grape, Izabella & 215 & 366 & 452 & 538 & 581 & 602 & 624 & 645 \\
\hline Gooseberry, Hauton & 378 & 643 & 794 & 945 & 1021 & 1058 & 1096 & 1134 \\
\hline
\end{tabular}

Considering the data obtained, it should be noted that with increasing the depth of penetration of the blade, the value of the cutting force increases. The change in ambient temperature helps reduce the cutting force, which is an inverse relationship. The lower the moisture content of the cut branch, the stronger the wood, and therefore a greater force must be applied to the blade of the pruner to cut it.

These calculations are the basis for designing a linear electric motor. The basis for the correct choice of a linear electric motor is its maximum developed force, which should be greater than the maximum cutting force of the branches by at least $30 \%$.

\section{Conclusions}

On the basis of the obtained results it can be concluded that the force of cutting branches of different cultures can differ several times (Gooseberry - $1134 \mathrm{~N}$, Grape - $645 \mathrm{~N}$ ). The choice of the developed force of the linear electric drive must be carried out according to the maximum values of the cutting force of the branches (Gooseberry - $1284 \mathrm{~N}$ ).

\section{References}

[1] Антонов С.Н. Проектирование систем электрификации (Designing of electrification systems). Textbook for the implementation of the course project. S.N. Antonov. - Stavropol: AGRUS SSAU, 2015 - 92 p. (In Russian)

[2] Антонов С.Н. Проектирование электропривода сельскохозяйственного назначения (Designing an electric drive for agricultural purposes) : a textbook / S.N. Antonov, D.V. Danilov; Stavropol State Agrarian University. - Stavropol: AGRUS, 2010. - 272 p. (In Russian)

[3] Никитенко Г. В., Домников А. А. Ручной электрифицированный секатор на основе линейного электропривода постоянного тока. (Manual electrified secateurs based on a linear electric drive of direct current). Methods and technical means to improve the efficiency of electricity in agriculture: Sat. scientific. tr. / St.SAU. - Stavropol, 2006. - P. 53-57. (In Russian)

[4] Пат. 2394342 Российская Федерация, МПК Н02K41/02, Н02К33/12. Линейный электродвигатель / Г. В. Никитенко, П. В. Жаворонков (Pat. 2394342 Russian Federation, IPC H02K41 / 02, H02K33 / 12. Linear electric motor) G.V. Nikitenko, P.V. Zhavoronkov; the applicant and the patent owner of the Stavropol State Agrarian University. 2009123794/09; claimed. 22.06.2009; publ. 07/10/2010, Bul. №19. 6 p. (In Russian)

[5] Резник H.M. Теория резания лезвием и основы расчета режущих аппаратов 9The theory of blade cutting and the basis for calculating cutting machines): M., "Mechanical Engineering", 1975. 311 p. (In Russian)

[6] Туриев О.И. Разработка и обоснование основных параметров обрезчика ветвей для крестьянских (фермерских) хозяйств (Development and justification of the main parameters of the cutter branches for peasant (farm) farms): diss. ... cand. tech. sciences. Vladikavkaz, 1999. 162 p. (In Russian)

[7] Hedrick U.P. Cyclopedia of Hardy Fruits. New York: The MacMillan Company, 1922. 370 pp.

[8] Csanády E., Magoss E. Mechanics of Wood Machining. 2-nd ed. Springer-Verlag Berlin Heidelberg, 2013. 199 p. 